\title{
Estabelecimento de cultura de células em suspensão e identificação de flavonóides em Cordia verbenacea DC.
}

\author{
AMEIRA, O.A..$^{*}$; PINTO, J.E.B.P. ${ }^{2}$; CARDOSO, M.G. ${ }^{2}$; ARRIGONI-BLANK, M.F. ${ }^{3}$ \\ ${ }_{1}^{1}$ Embrapa Amazônia Oriental, Belém, PA, CEP 66095-100 * osmar@cpatu.embrapa.br ${ }^{2}$ Departamento de \\ Agricultura, Universidade Federal de Lavras, Lavras, MG, CEP 37200-000, ${ }^{3}$ Universidade Federal de Sergipe, Rua \\ Cláudio Batista - Santo Antônio, Aracaju - SE, CEP 49060-100
}

\begin{abstract}
RESUMO: O trabalho teve como objetivos o estabelecimento de culturas de células em suspensão, extração, separação e identificação de flavonóides em extratos de folhas e de células em suspensão de Cordia verbenacea. Células dessa espécie, após terem sido subcultivadas três vezes no meio MS suplementado com 2,32 $\mu \mathrm{M}$ de cinetina $+10,74 \mu \mathrm{M}$ de ANA a intervalos de 28 dias, apresentaram cinco estágios de crescimento: as fases lag, exponencial, linear, desaceleração e estacionária. O maior percentual de crescimento (37\%) ocorreu no período exponencial entre o quarto e o décimo segundo dia e o menor (3\%) na fase lag até o quarto dia. Para identificação de flavonóides, foram usados extratos submetidos à separação e purificação por CCD e CCL e os componentes obtidos submetidos à Espectroscopia de Ultravioleta, Espectrometria de Infravermelho e Massa e Ressonância Magnética Nuclear de Hidrogênio. Após as frações das amostras de folhas e células terem sido separadas pelo eluente ácido acético, foram identificados os componentes 7,4'-diidróxi-5'-carboximetóxi isoflavona e 7,4'-diidróxi-5'-metil isoflavona. Foi detectado maior concentração dessas substâncias nas células cultivadas in vitro.
\end{abstract}

Palavras-chave: Cordia verbenacea, metabólitos secundários, cultura de tecidos

\begin{abstract}
Establishment of cell suspension cultures and flavonoid identification in Cordia verbenacea DC. The aims of this study were to establish cell suspension cultures, as well as to extract, separate and identify flavonoids in Cordia verbenacea leaf extracts and cell suspensions. Cells of this species were subcultivated three times in MS culture medium supplemented with $2.32 \mu \mathrm{M}$ kinetin $+10.74 \mu \mathrm{M}$ NAA at 28-day intervals, showing five growth stages: lag, exponential, linear, deceleration and stationary phases. The highest growth rate $(37 \%)$ occurred in the exponential phase between the fourth and the twelfth day and the lowest growth rate (3\%), in the lag phase until the fourth day. For flavonoid identification, extracts were separated and purified by TLC and LC and the obtained compounds were subjected to Ultraviolet Spectroscopy, Infrared and Mass Spectrometry, and Hydrogen Nuclear Magnetic Resonance. After leaf and cell sample fractions were separated using the eluent acetic acid, the compounds 7,4'-dihydroxy-5'-carboxymethoxy isoflavone and 7,4'-dihydroxy-5'-methyl isoflavone were identified. Higher concentrations of these substances were obtained in in vitro-cultivated cells.
\end{abstract}

Key words: Cordia verbenacea, secondary metabolites, tissue culture

\section{INTRODUÇÃO}

Cordia verbenacea, uma Boraginaceae popularmente conhecida como erva-baleeira, é um arbusto perene nativo que ocorre ao longo de todo o litoral brasileiro. Os princípios ativos básicos da planta são os óleos essenciais e os flavonóides, principalmente a artemetina. A principal ação terapêutica da artemetina, isolada por Sertie et al. (1990), é como antiinflamatório e antiinfeccioso para uso externo em ferimentos e contusões. Também é indicada para artrite, reumatismo e problemas de coluna, quando administrada internamente na forma de chá (Pinto et al., 2000). Muitas plantas superiores possuem capacidade para produzir um grande número de compostos orgânicos de alta diversidade estrutural, denominados

Recebido para publicação em 05/07/2006

Aceito para publicação em 17/10/2008

Rev. Bras. PI. Med., Botucatu, v.11, n.1, p.7-11, 2009. 
metabólitos secundários. Dentre estes, estão os compostos orgânicos produzidos da $C$. verbenaceae.

Os flavonóides têm uma importância potencial na medicina como inibidores de AMPcfosfodiesterase (Zuanazzi, 2000). Compreendem uma série de compostos secundários que ocorrem exclusivamente em plantas superiores, sendo responsáveis pela coloração das flores e que podem ser utilizados na determinação do parentesco de híbridos e em determinação de novos cultivares. Inúmeros desses compostos possuem atividades farmacológicas, destacando-se a artemetina, apigenina, taxifolina, morina, naringerina, genisteína e epicatequina. A naringerina reúne atividades indutoras da formação de hemoglobina, antiespasmódica e antihepatotóxica (Di Stasi, 1996).

Nos últimos anos, a cultura em suspensão de células vegetais tem sido usada como um sistema modelo para o estudo do mecanismo regulatório do metabolismo secundário em plantas superiores. Através deste modelo, é possível analisar a relação entre a produção do metabólito secundário e o crescimento em termos de número e morfologia celular (Karam et al., 2003; Furden et al., 2005).

O presente trabalho teve como objetivos 0 estabelecimento de culturas de células em suspensão, extração, separação e identificação de flavonóides em extratos de folhas e de células em suspensão de Cordia verbenacea.

\section{MATERIAL E MÉTODO}

\section{Estabelecimento de culturas de células em suspensão}

Calos de erva-baleeira foram obtidos a partir de segmentos caulinares cultivados em meio MS (Murashige \& Skoog, 1962), solidificado com 0,6\% de ágar, suplementado com 2,32 $\mu \mathrm{M}$ de Cinetina + $10,74 \mu \mathrm{M}$ de ANA (ácido naftaleno acético). Os calos foram subcultivados três vezes a intervalos de 28 dias no mesmo meio de cultura, com fotoperíodo de 16 horas (luz branca fria) sob $12,5 \mu \mathrm{mol} \mathrm{m}^{-2} \mathrm{~s}^{-1}$ de irradiância e uma temperatura de $27 \pm 1^{\circ} \mathrm{C}$. Posteriormente, $2 \mathrm{~g}$ de calos foram transferidos para erlenmeyers contendo $30 \mathrm{~mL}$ de meio líquido com a mesma composição do meio de indução de calos. Visando à produção de células em suspensão, esses calos foram cultivados sob agitação de $100 \mathrm{rpm}$ em fotoperíodo de 16 horas, sob $6,25 \mu \mathrm{mol} \mathrm{m}^{-2} \mathrm{~s}^{-1}$ de irradiância, onde foram mantidos até o final do experimento.

Para determinação da curva de crescimento, as células foram pesadas a intervalos de quatro dias, durante um período de 32 dias. Primeiramente, foi realizada a determinação da massa da matéria fresca.
Em seguida, as células foram colocadas em estufa a $45^{\circ} \mathrm{C}$ por 24 horas, e logo após, estimado a massa da matéria seca correspondente a cada matéria fresca. Cada pesagem foi proveniente de dez frascos retirados ao acaso. O percentual de crescimento das células foi determinado subtraindo a massa da matéria seca final (PF) da massa da matéria seca inicial (PI), dividindo este valor pela massa da matéria seca final e multiplicando por 100, através da fórmula [(PF - PI)/ PF] $\times 100$ (Smith, 1992).

\section{Extração, separação e identificação de flavonóides \\ Extração: Para obtenção da amostra de folhas} foram coletados $42 \mathrm{~g}$ de folhas verdes, provenientes de ramos com inflorescência de plantas de ervabaleeira com três anos de idade cultivadas em casa de vegetação. Após a coleta, as folhas foram secas em estufa a uma temperatura constante de $45^{\circ} \mathrm{C}$ por 24 horas. Em seguida, foram moídas e pesadas, obtendo-se $11,03 \mathrm{~g}$ que foram colocados em $200 \mathrm{~mL}$ de metanol, por um período de 48 horas. Posteriormente, foram filtradas procedendo-se a evaporação em um evaporador rotatório. O extrato seco foi colocado sob vácuo por 24 horas em um dessecador contendo sílica, cloreto de cálcio anidro $\left(\mathrm{CaCl}_{2}\right)$ e pentóxido de fósforo $\left(\mathrm{P}_{2} \mathrm{O}_{5}\right)$.

Separação: Do extrato obtido, $100 \mathrm{mg}$ foram diluídas em $5 \mathrm{~mL}$ de metanol e a mesma quantidade diluída em $5 \mathrm{~mL}$ de clorofórmio. Em seguida, foram preparadas lâminas para serem utilizadas em cromatografia de camada delgada (CCD). As amostras foram aplicadas nas cromatoplacas através de tubos capilares de vidro e colocadas em cubas cromatográficas nos seguintes solventes: clorofórmio (100\%); metanol + clorofórmio (1:1), (3:1); metanol + clorofórmio + água (56:36:8); hexano + metanol (1:1), (2:1), (1:2), (1:3), (1:4); ácido acético (100\%); ácido acético + metanol $(1: 1),(1: 2),(1: 3)$. Após o desenvolvimento do cromatograma, quando a fase móvel atingiu a parte superior das cromatoplacas, foi marcada a distância percorrida pela fase móvel. Em seguida, as cromatoplacas foram secas e reveladas na presença de iodo, em recipiente fechado. Posteriormente, foi marcada a distância percorrida pelas manchas desde a origem, e os resultados expressos através do fator de retenção - Rf (Mabry et al., 1970).

$\mathrm{Na}$ cromatografia líquida de coluna (CLC), foram utilizadas amostras provenientes de folhas obtidas como descrito anteriormente e de células obtidas de calos de erva-baleeira por meio de técnicas in vitro. No preparo da CLC foi utilizada sílica gel 60, diluída em clorofórmio puro e uma coluna com $45 \mathrm{~cm}$ de comprimento e 2,4 cm de diâmetro. Para calcular a quantidade de sílica a ser utilizada no preenchimento da coluna com $30 \mathrm{~cm}$ de altura, foi utilizada a fórmula:

Rev. Bras. Pl. Med., Botucatu, v.11, n.1, p.7-11, 2009. 
$\mathrm{V}=\pi \cdot \mathrm{R}^{2}$.h. $30 \%$, onde, $\mathrm{V}=$ peso da sílica a ser utilizada, $R=$ raio da coluna e $h=$ altura do enchimento da coluna desejada.

Extratos de folhas pesando $178 \mathrm{mg}$ foram diluídos em $5 \mathrm{~mL}$ de éter de petróleo e $100 \mathrm{mg}$ de extratos de células diluídas em $5 \mathrm{~mL}$ de metanol. Para separar os componentes da amostra, foram utilizados os seguintes solventes, na seqüência da menor para a maior polaridade: hexano, éter de petróleo, clorofórmio, metanol e ácido acético na amostra de folha, e os dois últimos na amostra de células. A vazão das frações coletadas foi de $1 \mathrm{~mL}$ por minuto. Em seguida, evaporou-se o solvente das frações coletadas.

Identificação: A determinação dos compostos foi realizada através das análises das estruturas por Espectroscopia de Ultravioleta (U.V), Espectrometria de Infravermelho (I.V), Espectrometria de Massa (EM) e Espectrometria de Ressonância Magnética Nuclear de Hidrogênio (RMN de ${ }^{1} \mathrm{H}$ ) (Ferri, 1996), além do ponto de fusão e solubilidade.

\section{RESULTADO E DISCUSSÃO}

\section{Estabelecimento de culturas de células em suspensão}

O crescimento de células apresentou estágios conforme apresentado na Figura 1. A fase lag, na qual as células preparam-se para a divisão, ocorreu até o quarto dia com o menor percentual de crescimento (3\%). A fase lag pode ser considerada como uma fase produtora de energia e a fase exponencial como a fase biossintética (Shimizu et al., 1977).
O período de máxima divisão celular ou período de crescimento exponencial ocorreu entre o quarto e décimo segundo dia com o maior percentual de crescimento (37\%). Esses resultados foram similares aos obtidos em Picrasma quassioides (Scragg \& Allan, 1993) e em Uncaria guianensis (Pereira et al., 2007). O período de crescimento linear ocorreu entre o décimo segundo e o vigésimo quarto dia, com $4 \%$ de crescimento. Nesse período, a divisão celular diminui e as células crescem (Smith, 1992). O período de desaceleração do crescimento ocorreu entre o vigésimo quarto e vigésimo oitavo dia, com $13 \%$ de crescimento. As culturas nesse período devem ser transferidas para um meio fresco devido à redução de nutrientes, produção de produtos tóxicos e a redução de $\mathrm{O}_{2}$ no interior das células e calos (Smith, 1992).

Após o período de crescimento, as células entram na fase estacionária onde há um maior número de células com menor capacidade de divisão celular e a célula entra em estágio de diferenciação celular. A fase estacionária ocorreu a partir do vigésimo oitavo dia. Nessa fase, geralmente ocorre o maior acúmulo de metabólitos secundários, porém com menor crescimento celular. Resultados semelhantes foram obtidos em Cissus sicyoides (Abreu, 1998).

\section{Identificação e separação de flavonóides}

$\mathrm{Na}$ CCD, os extratos diluídos em clorofórmio, geralmente apresentavam manchas formando um rastro sem haver separação, dificultando o cálculo de $R_{f}$. Na Tabela 1 são mostrados os valores de $R_{f}$ dos solventes que separaram as substâncias.

Os valores de $R_{f}$ revelaram que as substâncias foram separadas na presença dos

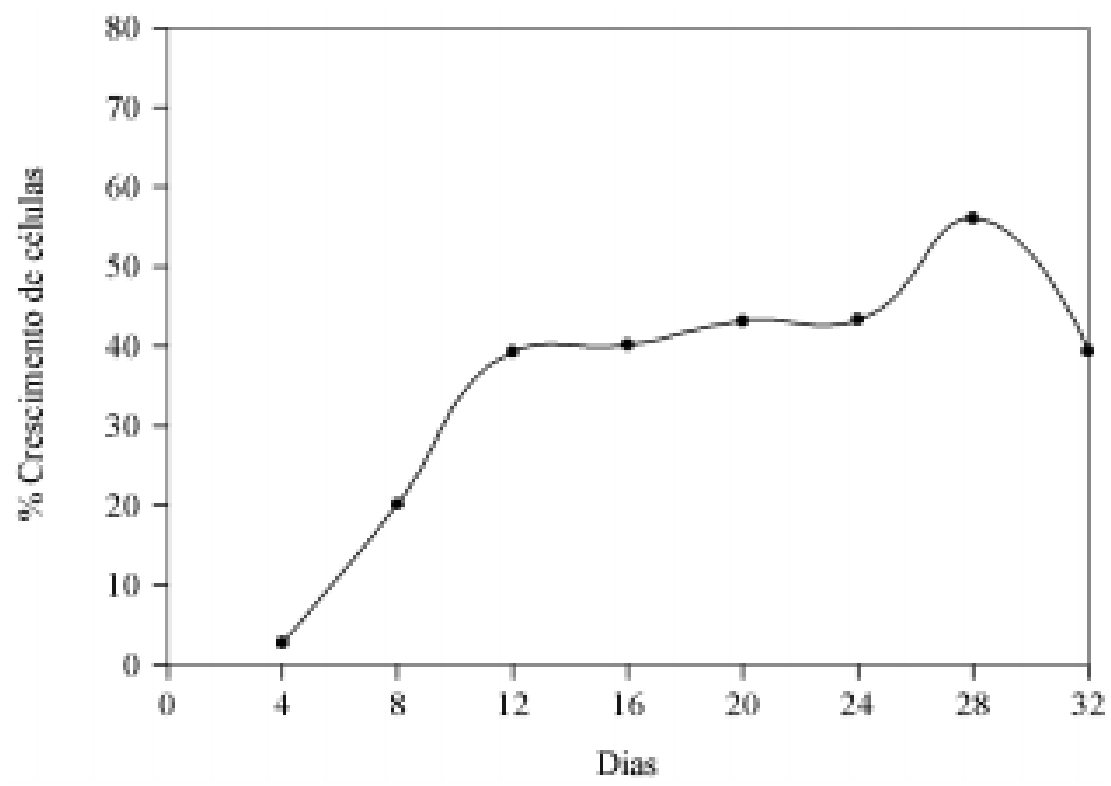

FIGURA 1. Percentual de crescimento de células em suspensão de Cordia verbenacea a partir da massa de matéria seca. 
solventes de maior polaridade, como metanol e ácido acético, isoladamente ou combinados entre si, além de metanol combinado com clorofórmio e água, metanol combinado com clorofórmio (3:1) e hexano combinado com metanol na proporção 1:4. Os menores valores de $R_{f}$ foram obtidos na presença de $\mathrm{AcOH}+\mathrm{MeOH}$, nas proporções 1:1 e 1:2 $(0,67)$, e de $\mathrm{MeOH}$ a $100 \%(0,69)$. Os maiores valores de $R_{f}$ $(0,93$ e 0,89$)$ foram obtidos quando foram utilizados como eluentes hexano $+\mathrm{MeOH}(1: 4)$ e $\mathrm{MeOH}+\mathrm{CHCl}_{3}$ $+\mathrm{H}_{2} \mathrm{O}$ (56:36:8), respectivamente.

TABELA 1. Valores de $R_{f}$ obtidas na CCD sob vários solventes, em extratos diluídos em metanol.

\begin{tabular}{lcc}
\hline Solvente & Concentraçāo & $R_{f}$ \\
\hline Hexano + MEOH & $1: 4$ & 0,93 \\
$\mathrm{MeOH}+\mathrm{CHCl}_{3}$ & $3: 1$ & 0,77 \\
$\mathrm{MeOH}+\mathrm{CHCl}_{3}+\mathrm{H}_{2} \mathrm{O}$ & $56: 36: 8$ & 0,89 \\
$\mathrm{MeOH}$ & $100 \%$ & 0,69 \\
$\mathrm{ACOH}$ & $100 \%$ & 0,86 \\
$\mathrm{AcOH}+\mathrm{MeOH}$ & $1: 1$ & 0,67 \\
$\mathrm{ACOH}+\mathrm{MeOH}$ & $1: 2$ & 0,67 \\
$\mathrm{AcOH}+\mathrm{MeOH}$ & $1: 3$ & 0,86 \\
\hline
\end{tabular}

$\mathrm{MeOH}$ - metanol; $\mathrm{CHCl}_{3}$ - clorofórmio; $\mathrm{AcOH}$ - ácido acético

Coelho et al. (2007) obtiveram sucesso na separação de flavonóides e outros componentes do glicosídeo cianogênico em Zollernia ilicifolia quando utilizaram um sistema de solvente envolvendo metanol, clorofórmio e água. Embora exista considerável envolvimento das áreas especificadas para cada tipo de flavonóide, o valor $R_{\mathrm{f}}$ serve como um guia útil para interpretação preliminar do tipo de flavonóide (Mabry et al., 1970).

Na CLC, após as frações das amostras de folhas e células terem sido separadas pelo ácido acético, foram obtidos os seguintes resultados: I.V.: $i_{\mathrm{KBr}}\left(\mathrm{cm}^{-1}\right): 3500 ; 3000 ; 2400 ; 1550-1500 ; 1450$; 1000; 650. U.V: $0,27 \mathrm{mg}$ em metanol: I $=200 \mathrm{~nm}$ para folha e U.V: $0,36 \mathrm{mg}$ em metanol: $l=200 \mathrm{~nm}$ para célula. $\mathrm{RMN}^{-1} \mathrm{H}$ : $11,5(\mathrm{~s}) 1 \mathrm{H} ; 6-8(\mathrm{~m}) 9 \mathrm{H} ; 3,5(\mathrm{~d})$ $2 \mathrm{H}\left(\mathrm{C}_{17} \mathrm{H}_{12} \mathrm{O}_{7}\right)$ e $6-8(\mathrm{~m}) 9 \mathrm{H} ; 3,5$ (d) $2 \mathrm{H} ; 1,98$ (t) $3 \mathrm{H}$ $\left(\mathrm{C}_{15} \mathrm{H}_{12} \mathrm{O}_{5}\right)$ e respectivamente, 79 e $94 \mathrm{mg}$ de uma substância de cor amarelo-parda com o ponto de fusão de 328 a $330^{\circ} \mathrm{C}$, solúvel totalmente em água e parcialmente em metanol.

O espectro de absorção de ultravioleta em $100 \%$ de metanol revelou que os valores de absorbância obtidos pelos extratos de células foram maiores que os obtidos pelos extratos de folhas em todos os comprimentos de onda. Em $\lambda=200 \mathrm{~nm}$ foi obtido o maior valor, $0,36 \mu \mathrm{g}$ em metanol para células e $0,27 \mu \mathrm{g}$ em metanol para folhas (Figura 2).

$\mathrm{Na}$ determinação da estrutura de novos compostos são utilizados vários métodos de espectrometria, como IV, EM e RMN de ${ }^{1} \mathrm{H}$. Os grupos funcionais da molécula podem ser obtidos através dos espectros de IV. Normalmente, por meio da EM pode-se obter a fórmula molecular, assim como o padrão de fragmentação da molécula. A associação dessas informações com os dados obtidos a partir da determinação dos ambientes que circulam os núcleos de hidrogênio e carbono da molécula, obtidos

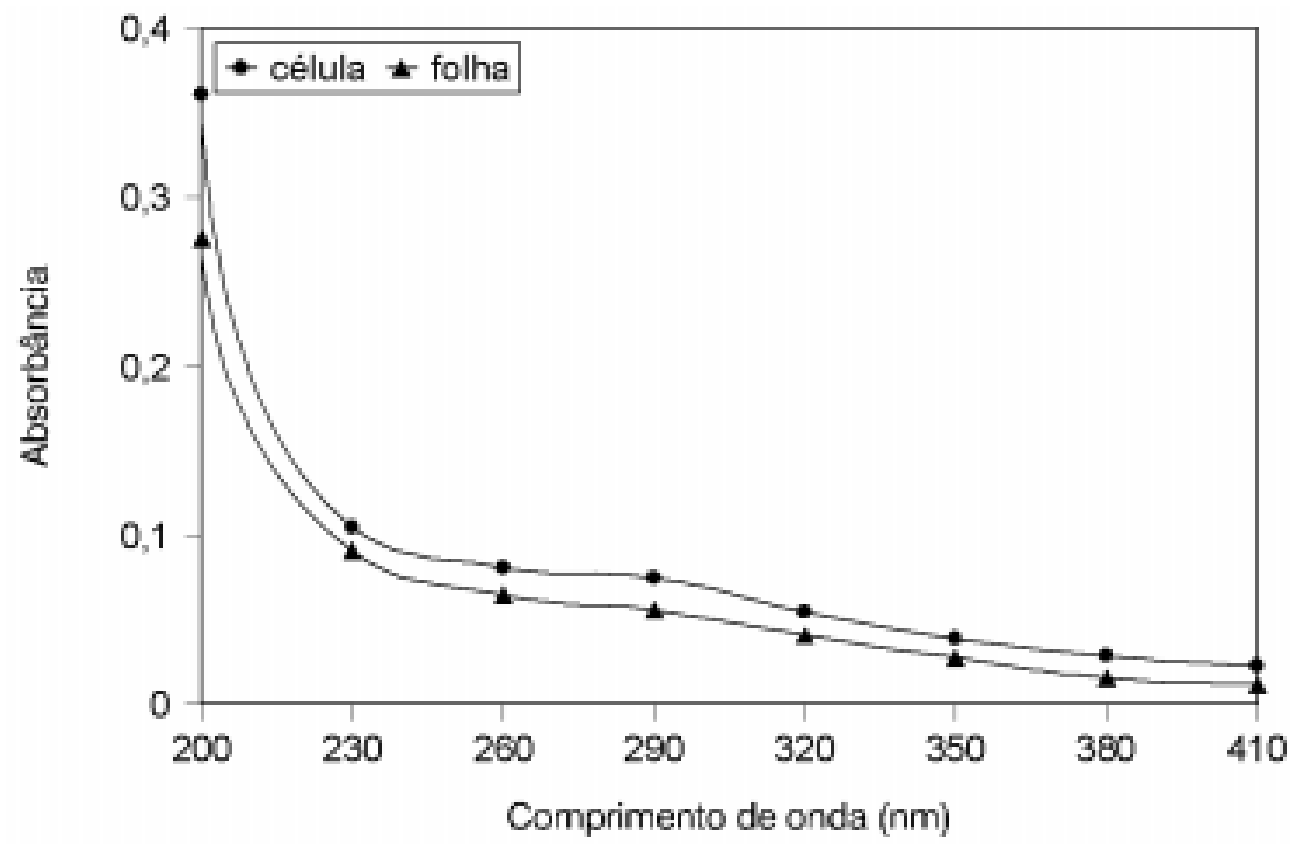

FIGURA 2. Espectro de absorção de ultravioleta em 100\% de metanol. 
respectivamente, pela $\mathrm{RMN}{ }^{1} \mathrm{H}$ e $\mathrm{RMN}{ }^{13} \mathrm{C}$, podem ser suficientes para elucidar uma determinada estrutura. Muitas vezes, a determinação do ponto de fusão da molécula oferece maiores dados para se chegar à estrutura (Ferri, 1996; Bertolucci et al., 2005).

O fracionamento do extrato hexânico das células e folhas de erva-baleeira resultou em uma fração cristalizável, cujos espectros no I.V, RMN de ${ }^{1} \mathrm{H}$ e de EM, indicaram tratar-se de uma mistura de

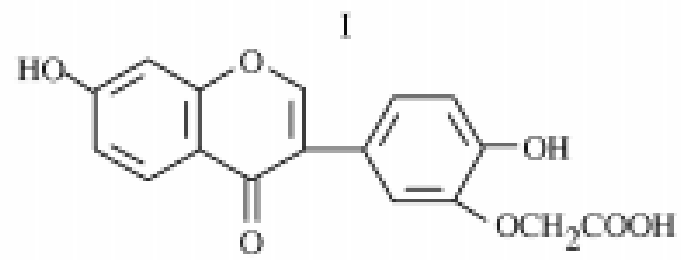

isoflavonóides. A partir dos dados obtidos e comparações com dados literários (Ferri, 1996), infere-se que os compostos encontrados em maior quantidade tanto em folhas quanto em células em suspensão são aqueles apresentados pelas estruturas I e II, respectivamente, $\mathrm{C}_{17} \mathrm{H}_{12} \mathrm{O}_{7}$ com 328

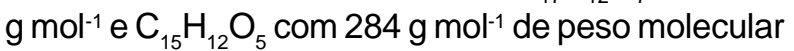
(Figura 3).

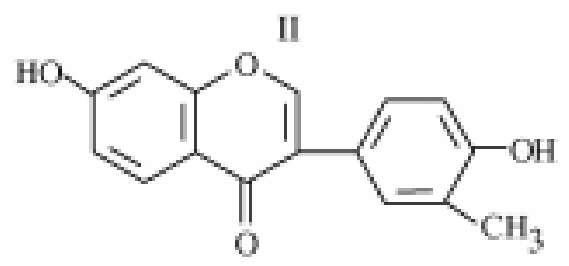

FIGURA 3. Estruturas moleculares dos compostos (I) 7,4'-diidroxi-5'-carboximetóxi isoflavona e (II) 7,4'-diidroxi-5'metil isoflavona identificadas nos extratos de erva-baleeira.

\section{CONCLUSÃO}

O crescimento de células em suspensão de C. verbenacea apresenta cinco estágios: fase lag, exponencial, linear, desaceleração e estacionária.

$\mathrm{Na}$ amostra de células cultivadas in vitro foi detectado maior concentração de substâncias do que na amostra de folhas, cujas análises indicam ser os flavonóides 7,4'-diidroxi-5'-carboximetóxi isoflavona e 7,4'-diidroxi-5'-metil isoflavona.

\section{REFERÊNCIA}

ABREU, I.N. Propagação in vivo e in vitro, calogênese, nutrição mineral e quantificação de mucilagem em Cissus sicyoides. 1998. 113p. Dissertação (Mestrado Área de Concentração em Fisiologia Vegetal) Departamento de Biologia, Universidade Federal de Lavras, Lavras.

BERTOLUCCI, S.K.V. et al. Abordagem fotoquímica preliminar em plântulas micropropagadas de Tournefortia cf paniculada Cham. Plant Cell Culture \& Micropropagation, v.1, n.2, p.59-65, 2005.

COELHO, R.G. et al. Separation of the toxic zierin from Zollernia ilicifolia by high speed countercurrent chomatography. Revista Brasileira de Plantas Medicinais, v.9, n.4, p.39-43, 2007.

DI STASI, L.C. Química de produtos naturais: princípios constituintes ativos. In: DI STASI, L.C. (Ed.). Plantas medicinais: arte e ciência. Um guia de estudo interdisciplinar. São Paulo: UNESP, 1996. p.109-27.

FERRI, P.H. Química de produtos naturais: métodos gerais. In: DI STASSI, L.C. (Ed.). Plantas medicinais: arte e ciência. Um guia de estudo interdisciplinar. São Paulo: UNESP, 1996. p.129-56.

FURDEN, B.V.; HUMBURG, A.; FUSS, E. Influence of methyl jasmonate on podophyllotoxin and 6mathoxypodophyllotoxin accumulation in Linum album cell suspension cultures. Plant Cell Reports, v.24, p.3127, 2005.

KARAM, N.S. et al. Growth and rosmarinic acid accumulation in callus, cell suspensión, and root cultures of wild Salvia fruticosa. Plant Cell, Tissue and organ culture, v.73, p.117-21, 2003.

MABRY, T.J.; MARKHAM, K,R.; THOMAS, M.B. The twodimensional paper chromatographic analysis of flavonoids. In: MABRY, T.J.; MARKHAM, K.R.; THOMAS, M.B. (Eds.). The systematic identification of flavonoids. Berlin: Springer-Verlag, 1970. p.3-15.

MURASHIGE, T.; SKOOG, F. A revised medium for rapid growth and biossays with tobacco tissue cultures. Physiologia Plantarum, v.15, n.3, p.473-97, 1962.

PEREIRA, R.C.A. et al. Influência de diferentes auxinas na indução e cinética de crescimento de calos de Uncaria guianensis J.F. Gmel. (Unha-de-gato). Plant Cell Culture \& Micropropagation, v.3, n.2, p.69-77, 2007.

PINTO, J.E.B.P.; SANTIAGO, E.J.A.; LAMEIRA, O.A. Compêndio de plantas medicinais. Lavras: UFLA/ FAEPE, 2000. 205p.

SCRAGG, A.H.; ALLAN, E.J. Picrasma quassioides Benett (Japanese Quassia Tree): In vitro culture and production of quassin. In: BAJAJ, Y.P.S. (Ed.). Biotechnology in agriculture and forestry: medicinal and aromatic plants IV. Berlin: Springer-Verlag, 1993. v.21, p.249-68.

SERTIE, J.A.A. et al. Antiinflamatory activity and sub-acute toxicity of artemetin. Planta Medica, v.56, n.11, p.36-40, 1990.

SHIMIZU, T. et al. Changes in metabolite levels during growth of Acer pseudoplatanus (sycamore) cells in batch suspension culture. Physiologia Plantarum, v.40, p.1259, 1977.

SMITH, R.M. Plant tissue culture: techniques and experiments. San Diego: Academic Press, 1992. 171p. ZUANAZZI, J.A.S. Flavonóides. In: SIMÕES, C.M.O. et al. (Eds.). Farmacognosia: da planta ao medicamento. Porto Alegre/Florianópolis: Ed. da Universidade/UFRGS/ Ed. da UFSC, 2000. p.489-544. 